EDUHEM 2018

VIII International conference on intercultural education and International conference on transcultural health: THE VALUE OF EDUCATION AND HEALTH FOR A GLOBAL, TRANSCULTURAL WORLD

\title{
THE ROLE OF STUDENTS' COMPETENCES FOR MOBILITY IN HIGHER EDUCATION
}

\author{
Carmen Carmona (a)*, Inmaculada López-Francés (b), Nerea Hernaiz-Agreda (c), Simran \\ Vazirani Mangnani (a) \\ *Corresponding author
}

(a) University of Valencia, Department of Research Methods and Educational Diagnosis, Av. de Blasco Ibáñez, 30, 46010, Valencia, Spain.*Email: Carmen.Carmona@uv.es

(b) University of Valencia, Department of Education Theory

(c) University of Valencia, Department of Didactics and School Organization

\begin{abstract}
Mobility programmes in higher education have become an option for academic development and a driver of future professional careers of Spanish university students. Therefore, some universities offer specific courses to prepare students in mobility skills. The present study focused on different factors that are relevant for students who have participated in the course "Intercultural competences for labour insertion: strategies for adaptation", offered by the University of Valencia. In particular, the study was carried out through a questionnaire that analyses whether students participating in the course (first edition) show intercultural and transversal competences that encourage a positive attitude towards academic and work mobility. Results indicate that students who intend to apply for a mobility scholarship and seek employment outside of Spain are less emotionally stable. In addition, students who have a greater willingness to seek employment outside Spain have developed their professional and vital project to a lesser extent. Students who are more open-minded adapt better to new situations, have daily relationships with people from other cultures, and feel more prepared professionally. Finally, the most independent students adapt better to new situations, and those who have contact with people from other cultures work better as a team, interact better socially, and adapt to new situations more easily. We conclude this study by emphasizing that intercultural and other transversal competences allow students who intend to study or work abroad to prepare better, academically and professionally, for mobility.
\end{abstract}

(C) 2019 Published by Future Academy www.FutureAcademy.org.UK

Keywords: Intercultural competences, mobility, training, university students. 


\section{Introduction}

Every year, thousands of students move to other countries to pursue their studies in higher education. However, many other students decide to stay at their home university. In fact, the academic mobility decision can result in hassles such as homesickness due to being away from the home country and pressure to satisfactorily perform one's studies, which can affect students' well-being (Pedersen, 2010).

Although the majority of students have previous international travel and leisure experiences and know the benefits of study abroad programmes, most of them will not pursue the possibility of enrolling in a study abroad programmes, even though there are extensive benefits of the mobility experience.

In particular, Van der Beek and Van Aart (2014) collected data from reviews from a survey conducted on the online platform "Student Experience Exchange," and 6,923 international students expressed their preferences about a range of aspects related to the host universities and cities. Results show that international students are generally very satisfied with their study abroad experience, and the factors that have the most influence on the students' satisfaction were: 1) City atmosphere, looks and size; 2) Academic subjects; 3) Teachers; and 4) International atmosphere. In this regard, the experience of international mobility is viewed as a specific aspect of youth citizenship, due to the fact that students do not locate themselves on either side of a geographical boundary, which is similar to the idea of 'the new mobile European' (Cairns, Krzaklewska, Cuzzocrea, \& Allaste, 2018; Ieracitano, 2014) and the Erasmus student 2.0 generation.

Thus, we need to analyze students' motivations for studying abroad and identify their needs and preferences in order to achieve successful academic and personal adaptation. In particular, previous research has found that students' main motivations before departure are mostly related to personal and professional matters, such as the belief that their upcoming stay abroad will be successful if it enables them to become more independent and self-confident (Asoodar, Baten, Van Maele, \& Vassilicos, 2014). Other studies reveal similar outcomes as those from the Erasmus Student Network survey, where exchange students indicated that their main motives for going abroad were meeting new people, learning about a different culture, and personal development (Messelink, Van Maele, \& Spencer-Oatey, 2015).

When students go abroad, they need to deal with different stages, such as issues before arrival or prearrival information, support on arrival, induction and welcome, learning in the classroom (academics) and learning in a new environment or life outside the classroom, and completion and return (reverse cultural shock). Previous research on this topic revealed that the most relevant issues are not only related to academic programmes, student exchange, and research and scientific collaborations, but also to extracurricular activities, external relations, and services at the universities (De Wit, 2011; De Wit, Hunter, Howard, \& Egron-Polak, 2015; Pérez-Encinas, \& Rodríguez-Pomeda, 2018).

Moreover, the mobility learning process is also linked to broader developments taking place during the mobility experience, stressing not only interculturality, but also preparation for the graduate labour market (Devlin, Kristensen, Krzaklewska, \& Nico, 2018). Some students have suggested that they should have prepared more before actually leaving their country and university. Therefore, it is important for prospective exchange participants to learn from the experience of former Erasmus students, regarding both the educational aspect of the exchange and the extracurricular activities. 
According to a review on outcomes of international student mobility programmes (Roy, Newman, Ellenberger, \& Pyman, 2018), in recent years researchers have identified a wide range of cultural outcomes resulting from participation in these programmes (e.g. Bohman \& Borglin, 2014; Dedee \& Stewart, 2003; Holtbrugge \& Engelhard, 2016; Luo \& Jamieson-Drake, 2015). These cultural outcomes include cultural awareness, cultural intelligence, global mindedness, cultural sensitivity and empathy, cultural adaptability, language skills, cross-cultural communication skills, and intercultural competence. All of them are competences required in today's society and encouraged by the European Union.

In particular, Erasmus students stress the importance of exploring new curricula, the possibility of participating in courses that are thematically different and conducted in a different way, and the use of a diverse range of pedagogical tools. This aspect may explain why accounts of the learning experience often compare education in the home country to education in the host university.

We state that students' attitudes towards risk, their experience with international travel, and their beliefs about being alone abroad could help to determine whether they express the intention to move abroad. However, competences that are developed or acquired during their university studies, such as initiative, flexibility, empathy, autonomy, communication, and dealing with diversity in different contexts and cultures, could be determinants in successfully studying and working abroad.

\section{Problem Statement}

There are many attributes of a study abroad programme that might affect whether a student enrolls in one of these programmes: price, location, duration, experiential learning activities that will occur in the programme, the student's familiarity with the language of the destination, the academic programme, the professor leading the programme, the subject material that the class will focus on, and whether and how the student earns credit towards graduation through the programme (Interis, Rezek, Bloom, \& Campbell, 2018). In addition, the study shows that students who express an interest in studying abroad have the following characteristics: (1) being less risk averse, (2) more likely to believe that studying abroad will help their career, and (3) more likely to have previous experience abroad. However, there are fewer studies that analyze the motives and transversal competences of a group of university students who attend training in "intercultural competences and the job market".

\section{Research Questions}

In the present research, we outline questions related to competences and mobility. Specifically, the main questions are: Do students enrolled in the course have previous academic mobility experience? Do these students have an interest in a mobility programme and the future decision to work abroad? Among those who have a mobility intention, are there differences in their transversal and intercultural competences? Which other factors are relevant to students with the intention to study or work abroad? 


\section{Purpose of the Study}

The present study aims to analyse motives to study or work abroad and their relationship with specific competences of university students who enrolled in a training programme on mobility and intercultural competences.

\section{Research Methods}

The method applied in the current research is empirical. We carried out the study with a questionnaire and quantitative analysis of the data collected.

\subsection{Participants}

Participants were 28 graduate students from the University of Valencia, Spain (10 males, 18 females; 25 Spanish, 1 Colombian, 1 Russian, and 1 from Algeria) who attended the first edition of the course on "Intercultural competences for labour insertion: strategies for adaptation". Among the participants, 57.1\% hold a degree in Finance and Administration, 14.3\% have a degree in Labour Relations, and the rest have university degrees related to Administration. The majority of the participants are in the last year of their degree studies. In all, $38.5 \%$ of participants have expressed the desire to apply for a mobility programme, but only $17.9 \%$ of the respondents have benefited from a European mobility grant. However, $89.3 \%$ have travelled abroad without any mobility programme. Some participants $(32.1 \%)$ intend to leave Spain to look for a job.

\subsection{Instrument}

Students completed a questionnaire designed to measure intercultural and general competences and other factors related to intention for mobility. The instrument has twelve questions on sociodemographics, family context, employment, mobility, and the parents' educational background, and three questions about satisfaction and learning in the course. In addition, two more Likert scales measure the following dimensions:

The Multicultural Personality Questionnaire (MPQ) (Van der Zee \& Van Oudenhoven, 2000, 2001, 2002) measures the multicultural effectiveness of expatriate employees and students. This questionnaire includes scales on cultural empathy, open-mindedness, emotional stability, social initiative, and flexibility. For this study, we used the validated 40-item short form (MPQ-SF) (Van der Zee, Van Oudenhoven, Ponterotto, \& Fietzer, 2013). Each item is then placed on a 5-point Likert-type scale ranging from 1 (not at all applicable) to 5 (completely applicable). All participants filled out the Spanish version of the questionnaire (Adalid, Carmona, Vidal, \& Sanchis, 2018; Carmona, Bravo, Hernaiz-Agreda, Salmerón, \& Sanchis, 2013).

CECTGRA questionnaire (Martínez Clares \& González Morga, 2018). The purpose of this questionnaire is to examine the development, domain, and relevance of some transversal competences included in the curricula of Spanish university degrees and the connection between university education and job market demands. This questionnaire has a global scale (development, domain, and relevance) and subscales (instrumental, personal, and systemic skills, respectively, for development, domain and relevance). Each subscale included a number of transversal skills measured with a set of questions in 57 items. This scale 
was chosen to study the students' perceptions about the development of their skills, rated on a five-point Likert scale from 1 (not at all applicable) to 5 (completely applicable).

\subsection{Procedure}

The questionnaire was administered during the course, and students participated voluntarily in the data collection as part of a course activity. It took approximately 20 minutes to complete. In this study, SPSS (Version 24.0) was used to carry out descriptive and multivariate statistical analyses.

\section{Findings}

Regarding multicultural personality competences, results showed some statistically significant differences in relation to graduate students who intend to apply for a mobility programme to study abroad. More specifically, the means for the variable Emotional Stability were higher for students who did not intend to apply for this type of scholarship $(M=3.35, S D=.634)$, than for those who did have the intention to request one ( $M=2.80, S D=.698, \mathrm{p} \leq .05)$. This result indicates that students who are less emotionally stable are more willing to study abroad, compared to students with greater stability. With regard to the students who had the intention to leave Spain to seek employment abroad, these people are still less emotionally stable $(M=2.74, S D=.727, \leq .05)$, compared to those who are more stable $(M=3.38, S D=.577, \mathrm{p} \leq .05)$.

No statistically significant differences were found in the rest of the intercultural competences. However, the results indicate that students with higher scores on open-mindedness are more willing to be employed in a foreign country, and students with more social initiative and cultural empathy have the intention to apply for a mobility programme.

Regarding the parents' educational background, the results indicate that a higher academic level of the mother increases the students' predisposition to apply for a mobility scholarship (p. $\leq$ ). In addition, related to knowledge of a foreign language and mobility and intention to work abroad, results indicated that there are no significant differences. However, there is a positive trend among students who are proficient in languages toward the intention to apply for a mobility programme or find a job abroad. No significant correlations were found between the multicultural personality competences and foreign language expertise. Moreover, a positive correlation was found between open-mindedness $(M=3.80, S D=.60, \mathrm{p}=.05)$ and flexibility $(\mathrm{M}=2.69, S D=.52, \mathrm{p}=.05)$. In both cases, the results show that if the student has greater openmindedness, s/he will also be more flexible and vice versa.

Finally, in relation to transversal competences, results show that students who wanted to have a job abroad had a higher level of competence in the development of their professional and vital project and decision making, and students with less emotional control had a greater predisposition to being employed outside of Spain.

\section{Conclusion}

In general, the results suggest that certain competences are more related to a positive intention to study or work abroad. Students' willingness to move abroad is not the most important factor encouraging them to make that decision. As previous findings have shown, specific strategies to help students make the 
decision can be related to activities focused on efforts to reduce students' fears of travelling abroad and enhance future professional paths that work experience abroad can bring to graduate students (Carmona, Marhuenda, Hernaiz-Agreda, \& Navas, 2018).

One important characteristic that mobility students express is that they substantially broaden their concept of where learning takes place during the exchange: it becomes associated not only with the foreign university, but also with factors adjacent to studying at the university (Cairns \& Smith, 2011). Academic mobility offers a holistic learning experience based on a learning process that involves mixing cultures, having encounters with other students and local inhabitants, travelling, and enjoying intercultural events, as well as the experience of everyday life (Krzaklewska \& Skórska, 2013).

The learning dimension of the experience is very much linked to the adventure of moving abroad: gathering new experiences, living in a foreign country, discovering another university campus, entering a different education system, trying things one has never done, being in new places, and meeting new people from all around the world. However, this 'unique experience' can only be shared as relevant learning in itself if a specific self- reflective strategy is provided. That is, guidelines are needed to transfer the experiential learning into strong and useful knowledge that supports the learning to learn competence developed by working and studying abroad.

\section{References}

Adalid, M., Carmona, C., Vidal, J., \& Sanchis, M. J. (2018). Competencias interculturales en Educación Superior: Aspecto clave para la movilidad. Education in the Knowledge Society, 19(1), 97-114.

Asoodar, M., Baten, L., Van Maele, J., \& Vassilicos, B. (2014). Criteria for a successful Erasmus experience: student perceptions in the IEREST project. D. Gallingani. IEREST Conference: Teaching the Intercultural in Contexts of Student Mobility (pp.1-10) University of Bologna, June $12-13$.

Bohman, D. M., \& Borglin, G. (2014). Student Exchange for Nursing Students: Does It Raise Cultural Awareness? A Descriptive, Qualitative Study. Nurse Education in Practice, 14, 259-64.

Cairns D., Krzaklewska E., Cuzzocrea V., \& Allaste A. A. (2018). Erasmus Learning. In D. Cairns, E. Krzaklewska, V. Cuzzocrea, and A.A. Allaste (Eds.), Mobility, Education and Employability in the European Union (pp. 77-101). Switzerland: Palgrave Macmillan.

Cairns, D., \& Smyth, J. (2011). I wouldn't mind moving actually: Exploring student mobility in Northern Ireland. International Migration, 49(2), 135-161.

Carmona, C., Bravo, M. J., Hernaiz-Agreda, N., Salmerón, A. G., \& Sanchis, M. J. (2013). Diversidad cultural y competencias interculturales. Investigación e Innovación Educativa al Servicio de Instituciones y Comunidades Globales, Plurales y Diversas. In Actas del XVI Congreso Nacional/II Internacional Modelos de Investigación Educativa de la Asociación Interuniversitaria de Investigación Pedagógica (AIDIPE) (pp. 1063-1070). Alicante: Universidad de Alicante.

Carmona, C., Marhuenda Fluixá, F., Hernaiz-Agreda, N., \& Navas Saurin, A. A. (2018). Educated for migration? Blind spots around labor market conditions, competence building, and international mobility. European Educational Research Journal, 17(6), 809-824.

Curtis, T., \& Ledgerwood, J. R. (2018). Students' motivations, perceived benefits and constraints towards study abroad and other international education opportunities. Journal of International Education in Business, 11(1), 63-78. doi:10.1108/JIEB-01-2017-0002

De Wit, H. (2011). Globalisation and internationalisation of higher education. RUSC, 8(2), 241-247.

De Wit, H., Hunter, F., Howard, L., \& Egron-Polak, E. (2015). Internationalization of higher education. Luxembourg: Publications Office of the European Union-European Parliament.

Dedee, L. S., \& Stewart, S. (2003). The Effect of Student Participation in International Study. Journal of Professional Nursing, 19, 237-42. 
Devlin, M., Kristensen, S., Krzaklewska, E., \& Nico, M. (Eds.). (2018). Learning mobility, social inclusion and non-formal education: Access, processes and outcomes. Strasbourg: Council of Europe.

Holtbrugge, D. \& Engelhard, F. (2016). Study Abroad Programs: Individual Motivations, Cultural Intelligence, and the Mediating Role of Cultural Boundary Spanning. Academy of Management Learning \& Education, 15, 435-55. doi:10.5465/amle.2015.0128.

Ieracitano, F. (2014). New European citizens? The erasmus generation between awareness and scepticism.

European Journal of Research on Social Studies, 1(1), 16-21. doi: 10.15526/ejrss.201416199

Interis, M. G., Rezek, J., Bloom, K., \& Campbell, A. (2018). Assessing the value of short-term study abroad programmes to students, Applied Economics, 50(17), 1919-1933,

Krzaklewska, E., \& Skórska, P. (2013). Culture shock during Erasmus exchange-Determinants, processes, prevention. In B. Feyen \& E. Krzaklewska (Eds.), The Erasmus phenomenon-Symbol of a new European generation (pp. 105-126). Frankfurt: Peter Lang.

Luo, J., \& Jamieson-Drake, D. (2015). Predictors of study abroad intent, participation, and college outcomes. Research in Higher Education, 56(1), 29-56.

Martínez Clares, P., \& González Morga, N. (2018). Las competencias transversales en la universidad: propiedades psicométricas de un cuestionario. [Transversal competences at university: psychometric properties of a questionnaire]. Educación XX1, 21(1), 231-262, doi: 10.5944/educXX1.15662

Messelink, H. E., Van Maele, J., \& Spencer-Oatey, H. (2015). Intercultural competencies: what students in study and placement mobility should be learning. Intercultural Education, 26(1), 62-72. doi: $10.1080 / 14675986.2015 .993555$

Pedersen, P. J. (2010). Assessing intercultural effectiveness outcomes in a year-long study abroad program.

International Journal of Intercultural Relations, 34, 70-80, doi: 10.1016/j.ijintrel.2009.09.003

Pérez-Encinas, A., \& Rodríguez-Pomeda, J. (2018). International Students’ Perceptions of Their Needs When Going Abroad: Services on Demand. Journal of Studies in International Education, 22(1), 20-36.

Roy, A., Newman, A., Ellenberger, T., \& Pyman, A. (2018). Outcomes of international student mobility programs: a systematic review and agenda for future research. Studies in Higher Education, 115, doi: 10.1080/03075079.2018.1458222

Van der Beek, C., \& Van Aart, J. (2014). Key influencers of international student satisfaction in Europe.

Eindhoven, The Netherlands: StudyPortals.

Van der Zee, K. I., \& van Oudenhoven, J. P. (2000). The Multicultural Personality Questionnaire: A multidimensional instrument of multicultural effectiveness. European Journal of Personality, 14, 291-309.

Van der Zee, K. I., Van Oudenhoven, J. P., Ponterotto, J. G., \& Fietzer, A. W. (2013). Multicultural Personality Questionnaire: Development of a short form. Journal of personality assessment, 95(1), 118-124

Van der Zee, K.I., \& Van Oudenhoven, J.P. (2001). The Multicultural Personality Questionnaire: Reliability and Validity of Self and Other Ratings of Multicultural Effectiveness. Journal of Research in Personality, 35, 278-288.

Van Oudenhoven, J. P. \& Van der Zee, K. I. (2002). Prediciting multiculural effectiveness in international students: The Multicultural Personality Questionnaire, International Journal of Intercultural Relations, 26(6), 679-694. 